\title{
The Pasteurella haemolytica 35 kDa iron-regulated protein is an FbpA homologue
}

\author{
S. D. Kirby, ${ }^{1}$ F. A. Lainson, ${ }^{2}$ W. Donachie, ${ }^{2}$ A. Okabe, ${ }^{3}$ M. Tokuda ${ }^{4}$ \\ O. Hatase ${ }^{4}$ and A. B. Schryvers ${ }^{1}$
}

Author for correspondence: S. D. Kirby. Tel: +1 403 2206047. Fax: +1 4032702772

e-mail: sdkirby@acs.ucalgary.ca

1 Department of Microbiology and Infectious Diseases, University of Calgary, Calgary, Alberta, Canada T2N 4N1

2 Moredun Research Institute, International Research Centre, Pentlands Science Park, Bush Loan, Penicuik, Midlothian EH26 OPZ, UK

3 Department of Microbiology ${ }^{3}$ and First Department of Physiology4, Kagawa Medical University, Kita-gun, Kagawa, 761-07, Japan
In a previous investigation, a $35 \mathrm{kDa}$ iron-regulated protein was identified from total cellular proteins of Pasteurella haemolytica grown under irondepleted conditions. This study reports identification of the gene (fbpA) encoding the $35 \mathrm{kDa}$ protein based on complementation of an entA Escherichia coli strain transformed with a plasmid derived from a P. haemolytica lambda ZAP II library. Cross-reactivity was demonstrated between an anti-35 kDa mAb and a $35 \mathrm{kDa}$ protein expressed in this strain. Furthermore, a translated ORF identified on the recombinant plasmid corresponded with the $\mathbf{N}$-terminal amino acid sequence of the intact and a CNBr-cleaved fragment of the $35 \mathrm{kDa}$ iron-regulated protein. Nucleotide sequence analysis of the gene encoding the $35 \mathrm{kDa}$ protein demonstrated homology with the cluster 1 group of extracellular solute-binding proteins, especially to the iron-binding proteins of this family. Complete sequence analysis of the recombinant plasmid insert identified three other predominant ORFs, two of which appeared to be in an operonic organization with fbpA. These latter components ( $f b p B$ and $f b p C$ ) showed homology to the transmembrane and ATPase components of ATPbinding cassette (ABC)-type uptake systems, respectively. Based on amino acid/DNA sequencing, citrate competition assay of iron affinity and visible wavelength spectra, it was concluded that the $P$. haemolytica 35 kDa protein functions as an FbpA homologue (referred to as PFbpA) and that the gene encoding this protein is part of an operon comprising a member of the FbpABC family of iron uptake systems. Primary sequence analysis revealed rather surprisingly that PFbpA is more closely related to the intracellular $\mathrm{Mn} / \mathrm{Fe}$ binding protein IdiA found in cyanobacteria than to any of the homologous FbpA proteins currently known in commensal or pathogenic members of the Pasteurellaceae or Neisseriaceae.

Keywords: Pasteurella haemolytica, iron, FbpA, ABC transporter

\section{INTRODUCTION}

Iron is an essential and limiting resource in most environments. In the mammalian host this is largely due to the iron-sequestering effects of the mammalian ironbinding proteins transferrin (in sera) and lactoferrin (on mucosal surfaces). In response to the difficulties associated with acquiring iron, many micro-organisms

Abbreviations: ABC, ATP-binding cassette; HFbpA, Haemophilus influenzae FbpA; PFbpA, Pasteurella haemolytica FbpA.

The GenBank accession number for the complete nucleotide sequence of the PBSPH1 recombinant insert reported in this paper is AF047427. have developed high-affinity iron acquisition systems to obtain this nutrient (Mietzner \& Morse, 1994). The expression of genes encoding proteins involved in the iron acquisition process is often coordinately regulated by the availability of. iron. In bacterial pathogens, low levels of iron serve as a signal for expression of a number of bacterial genes involved in adaptation to the host, including genes responsible for the pathogenesis of infection. Thus, proteins expressed under iron-limited conditions may be of essential function for bacterial survival and may ultimately serve as immuno- or chemotherapeutic targets.

Pasteurella haemolytica is the causative agent of bovine 
pneumonic pasteurellosis (shipping fever), responsible for a significant economic loss to the cattle industry. Initial difficulties encountered in developing vaccines to $P$. haemolytica prompted investigators to identify and study proteins which were preferentially expressed under iron-limiting conditions. A number of such ironregulated proteins have been identified, including proteins of molecular mass $100,77,71,42,35$ and $31 \mathrm{kDa}$ (Deneer \& Potter, 1989; Murray et al., 1992; Tabatabai \& Frank, 1997). The $100 \mathrm{kDa}$ protein has been demonstrated to possess transferrin-binding activity (Ogunnariwo \& Schryvers, 1990; Gray-Owen \& Schryvers, 1996) and the genes encoding the 100 and $71 \mathrm{kDa}$ proteins in $P$. haemolytica have since been cloned, sequenced and identified as the TbpA and $\mathrm{TbpB}$ transferrin-binding receptors (Ogunnariwo et al., 1997).

TbpA and TbpB form a host-specific outer-membrane receptor complex necessary for the removal of iron from transferrin at the cell surface (Gray-Owen \& Schryvers, 1996). The TbpB receptor is a largely hydrophilic molecule, believed to be anchored to the cell surface through a lipidated acyl tail (Gray-Owen \& Schryvers, 1996). The TbpA receptor is believed to function as an integral membrane gated porin through which iron is translocated after having been removed from transferrin. Upon removal from transferrin and translocation across the outer membrane, iron becomes associated with a periplasmic ferric-ion-binding protein ( $\mathrm{FbpA}$ ). FbpA has been demonstrated to function in complexing and transporting this iron through the periplasmic space (Chen et al., 1993; Kirby et al., 1997; Khun et al., 1998). FbpA is the periplasmic component of an iron ATPbinding cassette $(A B C)$ transporter system (Tam \& Saier, 1993), which also includes an inner-transmembrane protein, $\mathrm{FbpB}$, and a cytoplasmic ATPase, FbpC (believed to be necessary for the transport of FbpA-bound iron across the inner membrane and mobilization of iron from $\mathrm{FbpA}$, respectively). This integrated cascade of proteins results in transferrinbound iron being mobilized from the cell surface, transported through the periplasmic space and deposited into the cytoplasm without the incorporation of the transferrin molecule into the bacterial cell.

In a previous investigation, a $35 \mathrm{kDa}$ iron-regulated protein was identified by comparison of autoradiographic patterns between iodinated total cellular proteins of $P$. haemolytica grown in iron-replete and iron-depleted media (Lainson et al., 1991). An anti$35 \mathrm{kDa} \mathrm{mAb}$ demonstrated this protein to be localized in the periplasm. It was proposed that the $35 \mathrm{kDa}$ protein, given its size, location and regulation, may function in the uptake or transport of chelated iron. In this investigation, we undertook to identify and characterize the gene encoding the $35 \mathrm{kDa}$ protein using a $P$. haemolytica phagemid library to complement in trans an iron-utilization-deficient strain of Escherichia coli. Evidence is provided that the $P$. haemolytica $f b p A$ gene encodes the $35 \mathrm{kDa}$ protein. Biochemical properties of the $P$. haemolytica FbpA protein are examined and its relationship to other known FbpA proteins is presented.

\section{METHODS}

Strains and growth media. Bacterial strains, plasmids and deoxyoligonucleotides used in this study are shown in Table 1. $P$. haemolytica and E. coli strains were both stored in $30 \%$ glycerol at $-70^{\circ} \mathrm{C}$. Fresh $P$. haemolytica cultures were grown on BHI (brain-heart-infusion medium; Difco) plates incubated overnight at $37^{\circ} \mathrm{C}$ in a $5 \% \mathrm{CO}_{2}$ atmosphere. Fresh E. coli cultures were prepared on LA or LT plates [Luria agar (GibcoBRL) supplemented with $100 \mu \mathrm{g}$ ampicillin (Sigma) $\mathrm{ml}^{-1}$ or $12.5 \mu \mathrm{g}$ tetracycline (Sigma) $\mathrm{ml}^{-1}$, respectively] and incubated overnight at $37^{\circ} \mathrm{C}$. Liquid cultures of $P$. haemolytica were prepared in BHI broth. Liquid $E$. coli cultures were prepared in LA or LT broth (Luria broth base (Gibco-BRL) supplemented with $100 \mu \mathrm{g}$ ampicillin $\mathrm{ml}^{-1}$ or $12.5 \mu \mathrm{g}$ tetracycline $\mathrm{ml}^{-1}$, respectively]. Iron-restricted cultures of $P$. haemolytica were prepared by subculturing overnight $\mathrm{BHI}$ cultures into fresh $\mathrm{BHI}$ broth to an $\mathrm{OD}_{600}$ of $0 \cdot 2$, at which point the cultures were supplemented to $100 \mu \mathrm{M}$ with EDDHA (ethylenediamine-di(o-hydroxyphenylacetic acid); Sigma). Whole cells were used for Western blot analysis after an additional $2 \mathrm{~h}$ growth at $37^{\circ} \mathrm{C}$. NBDA agar $[8 \%(\mathrm{w} / \mathrm{v})$ nutrient broth (Difco), $5 \%(\mathrm{w} / \mathrm{v}$ ) NaCl, $1.5 \%$ (w/v) agar (Difco), pH 7.0 supplemented to $0 \cdot 2 \mathrm{mM}$ with 2,2'-dipyridyl (Sigma) and $100 \mu \mathrm{g}$ ampicillin $\left.\mathrm{ml}^{-1}\right]$ (Eick-Helmerich et al., 1987) and $2 \times$ Y'T broth $[16 \%(\mathrm{w} / \mathrm{v})$ Bactotryptone, $10 \%(\mathrm{w} / \mathrm{v})$ Bactoyeast extract, $5 \% \mathrm{NaCl}, \mathrm{pH} 7 \cdot 0$ ] were used in the library complementation experiment.

$\mathrm{N}$-terminal amino acid sequence analysis of the $35 \mathrm{kDa}$ protein. The $35 \mathrm{kDa}$ protein was semi-purified by reversedphase chromatography. It was then further purified by separation on SDS-PAGE gel, blotted onto Immobilon-P membrane (Millipore) and recovered for analysis. For internal sequencing, the $35 \mathrm{kDa}$ protein was affinity purified as previously described (Murray et al., 1992). It was then cleaved with $\mathrm{CNBr}$ and a $14 \mathrm{kDa}$ internal fragment was $\mathrm{N}$-terminally sequenced. Sequence analyses were carried out on an Applied Biosystems 470 gas-phase protein sequencer at the Babraham Research Institute, Cambridge, UK.

Complementation of e573 for growth on NBDA media using a $\boldsymbol{P}$. haemolytica lambda ZAP II library. Briefly, the following protocol [a hybrid of protocols described by Zimmermann et al. (1989) and Williamson \& Slocum (1994)] was used to complement e 573 (entA) for growth on NBDA media using a $P$. haemolytica h044 lambda ZAP II library (Stratagene). This library had been prepared as previously described for a Haemophilus influenzae library (Adhikari et al., 1995). e136 (SURE strain) and e573 (entA) cultures were grown in $50 \mathrm{ml}$ LT broth supplemented with $0 \cdot 2 \%$ maltose and $10 \mathrm{mM}$ $\mathrm{MgSO}_{4}$ overnight at $37^{\circ} \mathrm{C}$ in a shaking incubator. After overnight incubation the e 573 culture was stored until needed at $4^{\circ} \mathrm{C}$. Five microlitres of a $10^{10}$ p.f.u. $\mathrm{ml}^{-1} \mathrm{P}$. haemolytica lambda ZAP II library was diluted in $195 \mu \mathrm{l} 2 \times$ YT broth. Aliquots $(200 \mu \mathrm{l})$ of the diluted library were mixed with $200 \mu \mathrm{l}$ of an overnight e136 culture and $10 \mu \mathrm{l}$ of R408 helper phage $\left(7.5 \times 10^{10}\right.$ p.f.u. $\left.\mathrm{ml}^{-1}\right)$ and incubated at $37^{\circ} \mathrm{C}$ for $15 \mathrm{~min}$. The mixture was added to $5 \mathrm{ml}$ prewarmed $\left(37^{\circ} \mathrm{C}\right) 2 \times$ YT broth in a $15 \mathrm{ml}$ polypropylene tube and incubated for $3 \mathrm{~h}$ in a $37^{\circ} \mathrm{C}$ shaking incubator. The tube was then heated to $70^{\circ} \mathrm{C}$ for 20 min, centrifuged in a horizontal centrifuge at $4000 \mathrm{~g}$ for $15 \mathrm{~min}$ and the supernatant transferred to a fresh $15 \mathrm{ml}$ polypropylene tube. The resulting infective ss-pBluescript phagemid was immediately rescued to pBluescript plasmid by mixing $1 \mathrm{ml}$ phagemid supernatant with $1 \mathrm{ml}$ prewarmed e 573 in a stationary $37^{\circ} \mathrm{C}$ incubator for $20 \mathrm{~min}$. The $2 \mathrm{ml}$ of culture were then added to $50 \mathrm{ml}$ of $5: 1$ dilution of $\mathrm{BHI} / \mathrm{NBDA}$ broth 
Table 1. Bacterial strains, plasmids and primers

\begin{tabular}{|c|c|c|}
\hline $\begin{array}{l}\text { Strain, plasmid or } \\
\text { primer }\end{array}$ & Description & Source \\
\hline e136 & E. coli SURE strain $\left(\mathrm{Tet}^{\mathrm{R}}\right)$ & Stratagene \\
\hline e157 & E. coli $\mathrm{DH} 5 \alpha \mathrm{F}^{\prime}$ strain & Liss (1987) \\
\hline e201 & E. coli BL21(DE3) pLysS T7 expression strain & Novagen \\
\hline e1103 & e157 with plasmid pGEM PHFA & This study \\
\hline e1124 & e157 with plasmid pT7-7 PHFA & This study \\
\hline e1126 & e201 with plasmid pT7-7 PHFA & This study \\
\hline e1267 & e201 with plasmid pT7-7 & This study \\
\hline h044 & Serotype A1 P. haemolytica strain & S. Lundberg, Airdrie, Canada \\
\hline pBluescript SK II(+) & High-copy general cloning vector & Stratagene \\
\hline pBSPH1 & $\begin{array}{l}\text { pBluescript SK II }(+) \text { vector with recombinant } f b p A B C \text { insert } \\
\text { from h044 lambda ZAP II genomic DNA library }\end{array}$ & This study \\
\hline pGEM & T/A PCR cloning vector & Promega \\
\hline pGEM PHFA & 504-505 PHFA PCR product cloned into pGEM vector & This study \\
\hline pT7-7 & T7 expression vector & Tabor (1994) \\
\hline pT7-7 PHFA & $\begin{array}{l}\text { EcoRI/BamH1 PHFA fragment from pGEM PHFA cloned into } \\
\text { EcoRI/BamH1-cut pT7-7 }\end{array}$ & This study \\
\hline \multicolumn{3}{|l|}{ Primers } \\
\hline Oligo 504 & 5' AGAATTCCCTGTCTGAAGGAGACTATCATG 3' & This study \\
\hline Oligo 505 & 5' AGGATCCAAAAGTTGTTAGAGCAGCAATAC 3' & This study \\
\hline
\end{tabular}

and incubated overnight at $37^{\circ} \mathrm{C}$ in a shaking incubator. The cells were subcultured in broth, rather than directly plating to solid media, to provide an environment selective for growth (and subsequent enrichment of the culture) of those clones capable of growing under moderately iron-restricted conditions. After overnight incubation, $200 \mu \mathrm{l}$ of culture was plated in duplicate on LA agar (to determine the efficiency of the phagemid transfection) and NBDA agar (to select for clones capable of complementing the siderophore-deficient host). Pinpoint colonies on NBDA agar could be identified after $48-72 \mathrm{~h}$ incubation at $37^{\circ} \mathrm{C}$. Subsequent colonies were replated on NBDA agar. Colonies capable of regrowing on fresh NBDA agar were screened for siderophore production by plating on siderophore detection media (Schwyn \& Neilands, 1987). Clones negative for siderophore production were further investigated.

PCR and sequence analysis. PCR reactions were performed using Taq thermostable DNA polymerase (BRL) on a Perkin Elmer model 480 thermocycler. The following profile was used to amplify PCR products: $1 \times\left(94^{\circ} \mathrm{C}\right.$ for $\left.2 \mathrm{~min}\right)$, $30 \times\left(94^{\circ} \mathrm{C}\right.$ for $1 \mathrm{~min}, 50^{\circ} \mathrm{C}$ for $1 \mathrm{~min}, 72^{\circ} \mathrm{C}$ for $\left.1 \mathrm{~min}\right)$ and $1 \times\left(72{ }^{\circ} \mathrm{C}\right.$ for $\left.10 \mathrm{~min}\right)$. All other PCR parameters were performed as described by Innis \& Gelfand (1990). Plasmids were prepared for sequencing using a double-stranded nested deletion kit (Pharmacia). Derivatives of plasmids were prepared using Qiagen plasmid miniprep columns and sequencing was performed using Thermosequenase fluorescent dyeprimer cycle sequencing with 7-deaza-dGTP (Amersham) on a ABI PRISM 377 DNA sequencer.

Subcloning, overexpression and purification of $\boldsymbol{P}$. haemolytica FbpA (PFbpA). Oligodeoxynucleotide primers were designed to PCR-amplify the $f b p A$ gene, in order to clone and overexpress the gene product in $\mathrm{pT} 7-7$ vector (Tabor, 1994). Upstream primer 504 was designed to amplify the (predicted) native Shine-Dalgarno (underlined, Table 1) and coding (italicized ATG start codon, Table 1) regions of $f b p A$. It also possesses an EcoRI site for subcloning purposes (bold region, Table 1). Primer 505 was designed to amplify the intergenic region between $f b p A$ and $f b p B, 144$ bases downstream of the stop codon of $f b p A$, and possesses a $B a m \mathrm{H} 1$ site for subcloning purposes (bold region, Table 1). A 504-505 PCR product amplified from genomic h044 DNA was cloned into pGEM T-vector, constructing pGEM PHFA and strain e1103. The EcoRI/BamH1 fbpA cassette was removed from pGEM PHFA and spliced into similarly cut pT7-7 vector, producing pT7-7 PHFA and strain e1124. pT7-7 PHFA was transformed into the lambda lysogen E. coli strain BL21(DE3), which directs expression of T7 RNA polymerase under the control of the IPTG-inducible promoter, lacUV5, constructing strain e1126. PFbpA was overexpressed and purified from strain e1126 using IPTG induction and osmotic shock procedures described for the production and isolation of periplasmic maltose-binding fusion proteins from pMal-P2 (Riggs, 1994). Osmotic shock fluid was lyophilized and resuspended in appropriate buffers for further analysis.

Electrophoresis and Western blotting. All SDS-PAGE gels were run with the buffer system of Laemmli (1970). Urea denaturing IEF gels were run using Dry-IEF gels reconstituted with $6 \mathrm{M}$ urea/10 $\mathrm{mM}$ Tris $(\mathrm{pH} \mathrm{7.2)}$ on a Phast-gel electrophoresis system using carbamylyte calibration standards (Pharmacia). TAE (Tris/acetate/EDTA) agarose gels, standard molecular biology techniques and immunological analy- 
sis of electroblotted proteins were performed as previously described (Sambrook et al., 1989). Whole cells were applied to SDS-PAGE gels and a previously prepared murine $\mathrm{mAb}$ (Lainson et al., 1991) specific for the P. haemolytica $35 \mathrm{kDa}$ protein was used to develop the blots using ECL detection reagent (Amersham).

Buffer exchange, preparation of holo- and apo-PFbpA, wavelength scans and citrate competition assay. To prepare protein for IEF, protein samples were dialysed overnight with

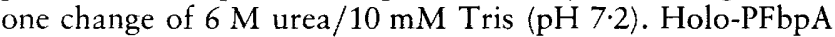
was prepared by resuspending lyophilized protein in $0.1 \mathrm{M}$ sodium citrate $/ 0 \cdot 1 \mathrm{M} \mathrm{NaHCO}_{3}$ buffer ( $\mathrm{pH} \mathrm{8.6)}$, adding 25fold molar excess $\mathrm{FeCl}_{3}$ and incubating at room temperature for $10 \mathrm{~min}$. The solution was then either gel-filtered using Econo-Pac 10 DG columns (Bio-Rad) or dialysed against two overnight changes of $10 \mathrm{mM}$ Tris $/ 200 \mathrm{mM} \mathrm{NaCl}$ (pH 8.0). Apo-PFbpA was prepared by resuspending the protein with $0 \cdot 1 \mathrm{M}$ sodium acetate $/ 0.1 \mathrm{M} \mathrm{NaH} \mathrm{PO}_{4}$ (pH 5.5), dialysing PFbpA against two overnight changes of $0 \cdot 1 \mathrm{M}$ sodium acetate $/ 0 \cdot 1 \mathrm{M} \quad \mathrm{NaH}_{2} \mathrm{PO}_{4} / 25 \mathrm{mM} \quad \mathrm{Na}_{2}$ EDTA $/ 0.4 \% \quad(\mathrm{w} / \mathrm{v})$ Chelex 100 (pH 5.5) and one overnight change of $10 \mathrm{mM}$ Tris $/ 200 \mathrm{mM} \mathrm{NaCl}(\mathrm{pH} 8 \cdot 0)$. Protein samples were quantified using a Bio-Rad $D_{c}$ Protein Assay and a Beckman DU-64 spectrophotometer. Wavelength scans of holo- and apoPFbpA were performed on a Beckman DU-640 spectrophotometer. Citrate competition assays of PFbpA iron affinity were performed as described by Chen et al. (1993), except that visible absorbance was monitored at the peak Fe absorbance for PFbpA (419 nm).

\section{RESULTS}

\section{Isolation of a P. haemolytica fbpABC operon}

Our approach to cloning the $f b p A$ gene was based on the premise that it would be part of an operon capable of mediating high-affinity iron transport in an E. coli mutant deficient in this process (Zimmerman et al., 1989). We used a siderophore-deficient (entA) strain as a host. This strain was incapable of growing on nutrient broth supplemented with the iron-chelating agent dipyridyl. The ent $A$ strain was transfected with a lambda ZAP II phagemid library generated from genomic DNA of a serotype A1 P. haemolytica strain (Ogunnariwo et al., 1997) and selected on the ironlimited medium. Upon selection, colonies were found which were negative for siderophore production, but positive for growth after replating on fresh iron-limited medium. One clone, designated e638, was randomly selected for further analysis.

Plasmid analysis of strain e638 yielded a recombinant plasmid, pBSPH1, with a $5.5 \mathrm{~kb}$ insert. Whole-cell Western blots were performed to determine if this recombinant strain expressed the previously identified $35 \mathrm{kDa}$ protein (Lainson et al., 1991). A mAb reacting with the $35 \mathrm{kDa}$ protein isolated from a serotype A2 strain of $P$. haemolytica was used to screen the electroblots. Extracts from iron-starved cells of both A1 and A2 serotypes were included in the analysis to ensure that the $\mathrm{mAb}$ was capable of detecting the $35 \mathrm{kDa}$ protein from a serotype A1 strain (the source of the genomic library). A single protein of $35 \mathrm{kDa}$ was detected in both serotypes of $P$. haemolytica, reaffirming the conserved

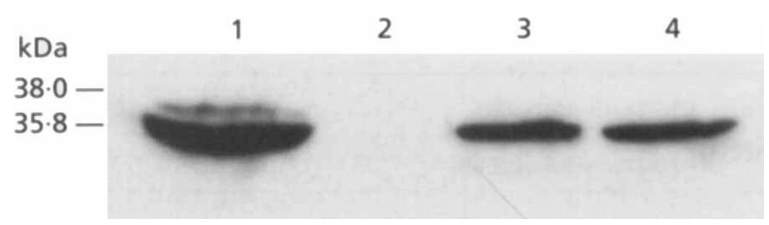

Fig. 1. Western blot analysis of $12 \%$ SDS-PAGE-separated whole-cell extracts of e638 (pBSPH1) (lane 1); e573 (entA host strain) (lane 2); h044 (serotype A1 P. haemolytica) (lane 3); and h098 (serotype A2 P. haemolytica) (lane 4). P. haemolytica cultures were iron-starved prior to analysis. Blots were probed with a previously prepared anti-35 kDa mAb (Lainson et al., 1991).

antigenic nature of this protein between A serotypes of $P$. baemolytica (lanes 3 and 4, Fig. 1; Murray et al., 1992). In e638 two bands were detected, a predominant band at $35 \mathrm{kDa}$ and a minor band at a slightly higher molecular mass (lane 1, Fig. 1).

\section{Sequence analysis of pBSPH1}

DNA sequence analysis of the 5527 bp insert in pBSPH1 identified four ORFs with homology to other known proteins (Fig. 2). Three of these ORFs appeared in tandem arrangement, while a fourth partial coding sequence was identified in opposite orientation to the former genes. The first ORF $(f b p A)$ encoded a protein which bears homology to the iron-binding proteins belonging to the cluster 1 group of periplasmic binding proteins (Tam \& Saier, 1993). A Shine-Dalgarno sequence immediately upstream of the $f b p A$ coding sequence corresponds to $9 / 13$ nucleotides of the $E$. coli consensus sequence (Shine \& Dalgarno, 1974). A potential -10 region (TAAGAA) region was also identified upstream of $f b p A$. The recombinant gene insert ends immediately upstream of this -10 region; however the fusion of the recombinant insert to the pBluescript SK II(+) vector appears to have created an artificial -35 region (TTGATA), generating a functional promoter. Previous work has indicated that $\mathrm{FbpA}$ is an iron-regulated protein (Lainson et al., 1991), but unfortunately truncation of the promoter/operator regions in $\mathrm{pBSPH} 1$ precludes analysis of this region or the potential search for a fur consensus sequence.

An intergenic region of $187 \mathrm{bp}$ with a number of potential regions of secondary structure separates $f b p A$ from a potential TTG start codon of the next ORF. The second ORF $(f b p B)$ encodes a highly hydrophobic protein with homology to the family of cytoplasmic membrane-spanning proteins believed to interact with the iron-binding cluster 1 periplasmic binding proteins. Based on this TTG start codon, the calculated molecular mass of $\mathrm{FbpB}$ would be $58.7 \mathrm{kDa}$. Two regions of $\mathrm{FbpB}$ match the permease consensus sequence EAA-- G-..-.---I-LP, common to the transmembrane component of these ABC transporter systems (Saurin et al., 1994; Adhikari et al., 1996). The third gene $(f b p C)$, with a 


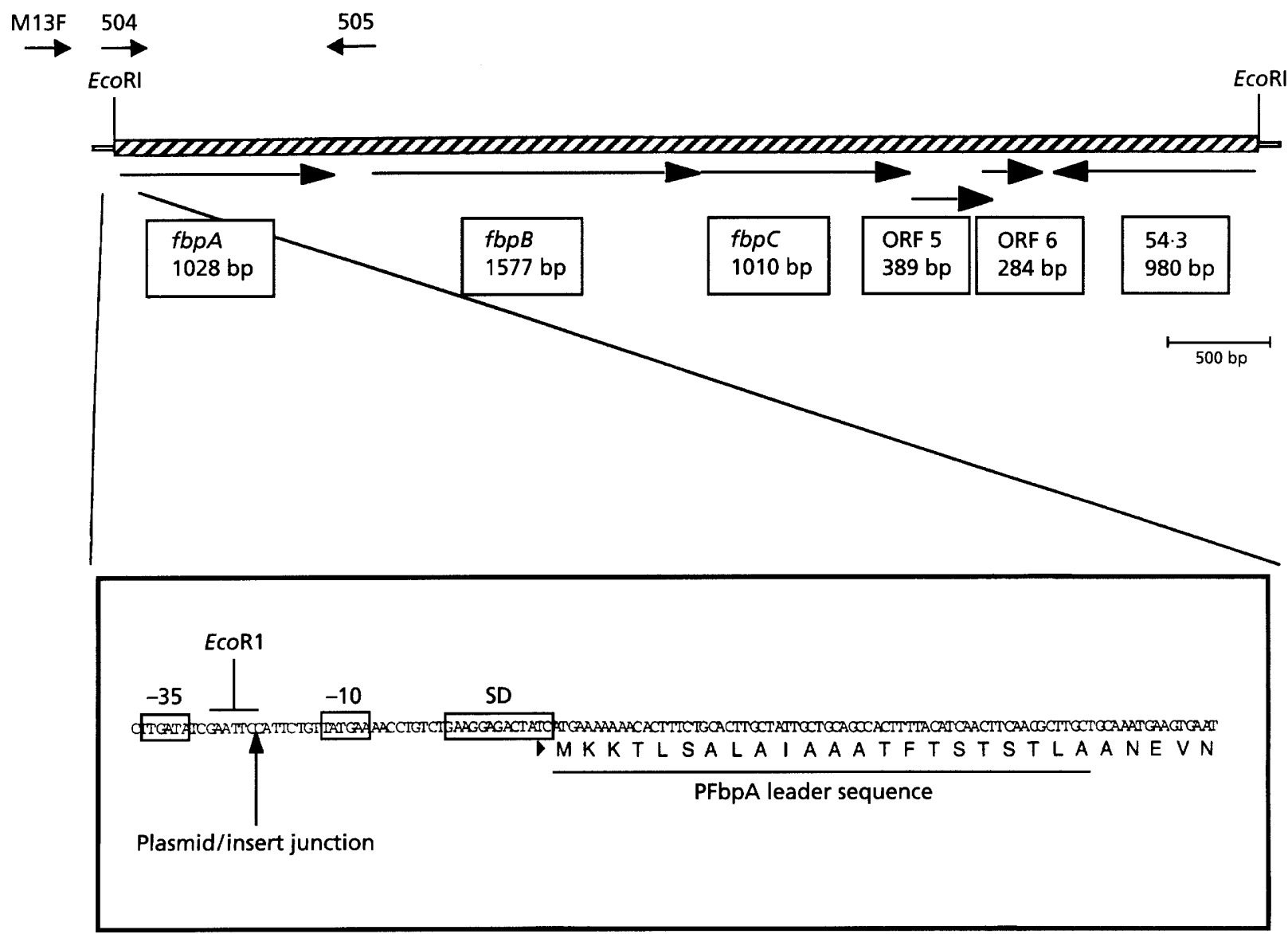

Fig. 2. Schematic representation of the $\sim 5.5 \mathrm{~kb}$ recombinant insert of pBSPH1. Illustrated are the flanking EcoRI sites in which the recombinant $P$. haemolytica library DNA was inserted into this pBluescript vector, positions and sizes of predicted ORFs identified within the recombinant insert and relative positions of the vector M13F and insert 504 and 505 primer sites. Enlarged are the nucleotide and translated amino acid sequences of the beginning of the $P$. haemolytica $f b p A$ gene and FbpA protein, respectively. Illustrated in the DNA sequence are the predicted -35 and -10 promoter and Shine-Dalgarno (SD) regions. Illustrated in the amino acid sequence is the leader peptide for FbpA.

calculated molecular mass of $37 \cdot 7 \mathrm{kDa}$, has the typical signature sequences of an ATPase (Walker A and B motifs; Higgins, 1992) and begins 9 bp downstream of FbpB. The fourth truncated ORF (54.3) illustrates homology to a hypothetical protein of $54 \cdot 3 \mathrm{kDa}$ (Burland et al., 1995) identified in the genome of E. coli $(51 \%$ identity with the available $P$. haemolytica sequence; $\sim 65 \%$ of the gene sequenced, based on comparison with the $E$. coli gene). Two small potential ORFs (Fig. 2) immediately following FbpC [ORF5 of $389 \mathrm{bp}(\sim 15 \mathrm{kDa})$ and ORF 6 of $284 \mathrm{bp}(\sim 10 \mathrm{kDa})]$ show no significant homology to any known proteins, but are reminiscent of the small potential ORF (524 bp; $\sim 19 \mathrm{kDa})$ following $s f u C$ of Serratia marcescens (Angerer et al., 1990).

The $f b p A$ gene encodes a $38 \mathrm{kDa}$ protein containing a characteristic signal sequence (Fig. 2) which is cleaved from the mature protein following secretion. The predicted size of the mature PFbpA which would be exported to the periplasm is $35 \cdot 8 \mathrm{kDa}$. Thus the higher molecular mass protein detected in Western blots of the strain containing pBSPH1 (Fig. 1) corresponds to the $38 \mathrm{kDa}$ unprocessed precursor protein of $\mathrm{PFbpA}$. As pBSPH1 is a high-copy plasmid, the presence of the higher molecular mass PFbpA in E. coli, but not in the native strains, may indicate a saturation of the $E$. coli periplasmic secretion apparatus. Two regions of the translated PFbpA protein correspond with the amino acid sequence derived from the $35 \mathrm{kDa}$ protein (Table 2), confirming that the $35 \mathrm{kDa}$ protein is encoded by the $f b p A$ gene. The $\mathrm{N}$-terminal amino acid sequence of the intact $35 \mathrm{kDa}$ protein corresponds exactly to that of the translated DNA sequence. In contrast, there are several differences between the experimentally determined amino acid sequence of the $14 \mathrm{kDa}$ polypeptide and the translated sequence from the $f b p A$ gene. This may represent an artifact of DNA- or amino acid sequencing or perhaps is attributable to differences between PFbpA from the $\mathrm{A} 1$ and $\mathrm{A} 2$ serotypes.

The predicted amino acid sequence of the mature PFbpA 
Table 2. $\mathrm{N}$-terminal amino acid sequences of the $35 \mathrm{kDa}$ PFbpA and $\mathrm{CNBr}$-cleaved $14 \mathrm{kDa}$ subfragment, and the corresponding translated DNA sequences of $f b p A$

Bracketed letters represent questionable amino acid identifications.

\begin{tabular}{|ll|}
\hline Sequence source & Peptide sequence \\
\hline PFbpA & \\
N-terminal sequence & ANEVNVYSYRQPYLIEPMLK \\
Translated DNA sequence & ANEVNVYSYRQPYLIEPMLK \\
$\mathbf{1 4}$ kDa fragment & \\
N-terminal sequence & MLDDEKQS (C) AEAAII (N) FPS \\
Translated DNA sequence & MLDDEKQKS W AEAAI N N FPS \\
\hline
\end{tabular}

\begin{tabular}{|c|c|}
\hline IdiA & .EG . . . L . . . HYNTDNQIYRE. TQK ..... . L.EGEATA. LA.L.S. .S \\
\hline $\mathrm{pp}$ & A-NEVNVYSYRQPYLIEPMLKNFEKDTGIKVNI IFADKG-LVDRVKQEGE \\
\hline $\mathrm{FbpA}$ & D--IT . NGQRKEAAAAVA.A. .QE. \\
\hline ¡A & R. $\ldots F I \ldots$. AG . LWQATQ. \\
\hline bpA & LSPADVLLTVDISRVMEIVNADLAQKID---SKVLEKNIPAQFRDSNDQW \\
\hline & EQTATFADLSE . G. LAP . SEQ--TIKQTAQKGVPLAPKKD. \\
\hline & -NASQLST.E. . .N.KWRNQI--L . ..SS.V. . \\
\hline A & FGLTTRARVIYTSKDRVGKLPAGFDYLDLAKPEYKGKV--CVRSGKNSYN \\
\hline & VA.SG.S. .VVYDHTKLSEKDMEKSV . .Y.T.KW...IGYVST . .AF--- \\
\hline & L . TGE . AAD. AA . E. WAR . VQ.F. .Q . . P TP. IA. CAA.VGSLA \\
\hline A & VSLFAAMIEHYGIEKTKAFLEGLKANLARKPQGGDRDQVKAIKEGICDYS \\
\hline & LEQVV. LSKMK. DKVALNW.K. . . F \\
\hline |A & $\begin{array}{l}\text { P } \mathbb{I I} \\
\text { A.T. . LVRLFKSK . AEER - . . R }\end{array}$ \\
\hline opA & IGNSYYYGKMLDDEKQKSWAEAA-II----NFP-SGEHGTHKNISGVVIA \\
\hline & LKSRLY . VRHQDP . ALVSY . . AAVL \\
\hline IF & RG.G. . . LR.VSLDP.LA. \\
\hline r & KHSPNKANAVKLIEYLSGEKAQC \\
\hline & A.K.Q.E.Q.FVDF.A \\
\hline & . ESK.S \\
\hline & EDIAKNYEAALKLVDEVKFDDFSEKK \\
\hline & TT.QDK.H. \\
\hline
\end{tabular}

IdIA .EG...L..G.HYNTDNQIYRE. TQK ..... L. LGEATA.LA.L.S. .S

PFbpA A-NEVNVYSYRQPYLIEPMLKNFEKDTGIKVNI IFADKG-LVDRVKQEGE

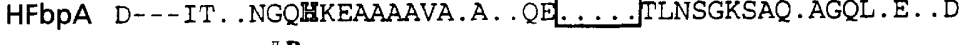

IdIA R. ....FI...AG. LWQATQ.N.LRPLTQAQAPKLYQAV. . NL . PQGR.

PFbPA LSPADVLLTVDISRVMEIVNADLAQKID---SKVLEKNIPAQFRDSNDQW

PPP
PFA

PFbPA FGLTTRARVIYTSKDRVGKLPAGFDYLDLAKPEYKGKV--CVRSGKNSYN

HFbpA VA.SG.S..VVYDHTKLSEKDMEKSV..Y.T.KW...IGYVST..AF--

IdiA L..TGE. AAD.AA. E.WAR..VQ.F. .Q....TP.IA.CAA.VGSLA

PFbPA VSLFAAMIEHYGIEKTKAFLEGLKANLARKPQGGDRDQVKAIKEGICDYS

IdiA $P \mathbb{P} \mathbb{I}$.

PFbPA IGNSYYYGKMLDDEKQKSWAEAA-II----NFP-SGEHGTHKNISGVVIA

HFbpA LI.N. . WYNLAKEKG------VENLKSRLY. VRHQDP. ALVSY. . AAVL

IdiA RTA..PRA.QL.L. ..LSSQ. .AVF.RG.G. ...LR.VSLDP.LA.F.Q.

PFbpA KHSPNKANAVKLIEYLSGEKAQGLYAELNHEYPVKEGIEPSAIVKGWGTF

IdiA .ESK.SASVFGA.NAQ..Q.M.RAGW-----

HFbPA LEAPVVSATT.QDK.H.T. .IE.AGL--.-.
Fig. 3. Primary sequence alignment between the mature proteins of $P$. haemolytica FbpA, Synechococcus sp. PCC6301 IdiA and $H$. influenzae FbpA. Boxed are the TGIKV and PADV sequences characteristic of the iron-binding protein subclass of cluster 1 periplasmic binding proteins. Outlined are the iron (0)-binding ligands and in bold are the phosphate (P)binding ligands known from the $H$. influenzae FbpA crystal structure (Bruns et al., 1997). Identical residues with reference to the PFbpA primary sequence are illustrated by dots; dashes represent spaces introduced to maximize alignment. was aligned with the sequences of homologues found in other bacterial species. Surprisingly, there was greater identity with IdiA (iron-deficiency-induced Protein $\underline{\text { A) }}$ from the cyanobacterium Synechococcus than with FbpA proteins from other pathogens, such as $H$. influenzae, belonging to the Pasteurellaceae (Fig. 3). The analysis also revealed that there are two short regions of identity which appear common to virtually all $\mathrm{Fe}$ binding proteins of this class (TGIKV and PADV) and thus may serve as signatures of this protein family. It is pertinent to note that these do not represent any of the amino acids involved in liganding the metal ion (Bruns et al., 1997). A dendrogram was compiled to illustrate the similarities and relationships of the various ironligand-binding proteins relative to one another and to the larger family of cluster 1 extracellular solute-binding proteins (Tam \& Saier, 1993), including the carbohydrate-binding proteins MalE, MalX, MsmE and
UgpB (Fig. 4). The resulting non-rooted tree was compiled using primary protein sequence comparison and the neighbour-joining method of the CLUSTAL w 1.6 program (Higgins et al., 1996). Confidence in the reliability of the branch points in the dendrogram is illustrated by the boxed bootstrap value assigned at each branch point (out of 10000 bootstrap samples).

\section{Biochemical characterization of PFbpA}

The $P$. haemolytica $f b p A$ gene was subcloned into the pT7-7 expression vector in order to provide substantial quantities of protein for further biochemical analysis. Simple overexpression of the recombinant $\mathrm{FbpA}$ and isolation of osmotic shock fluid provided a relatively pure preparation of protein. The process of iron loading and dialysis removed some minor contaminants such that the resulting protein was pure enough for bio- 


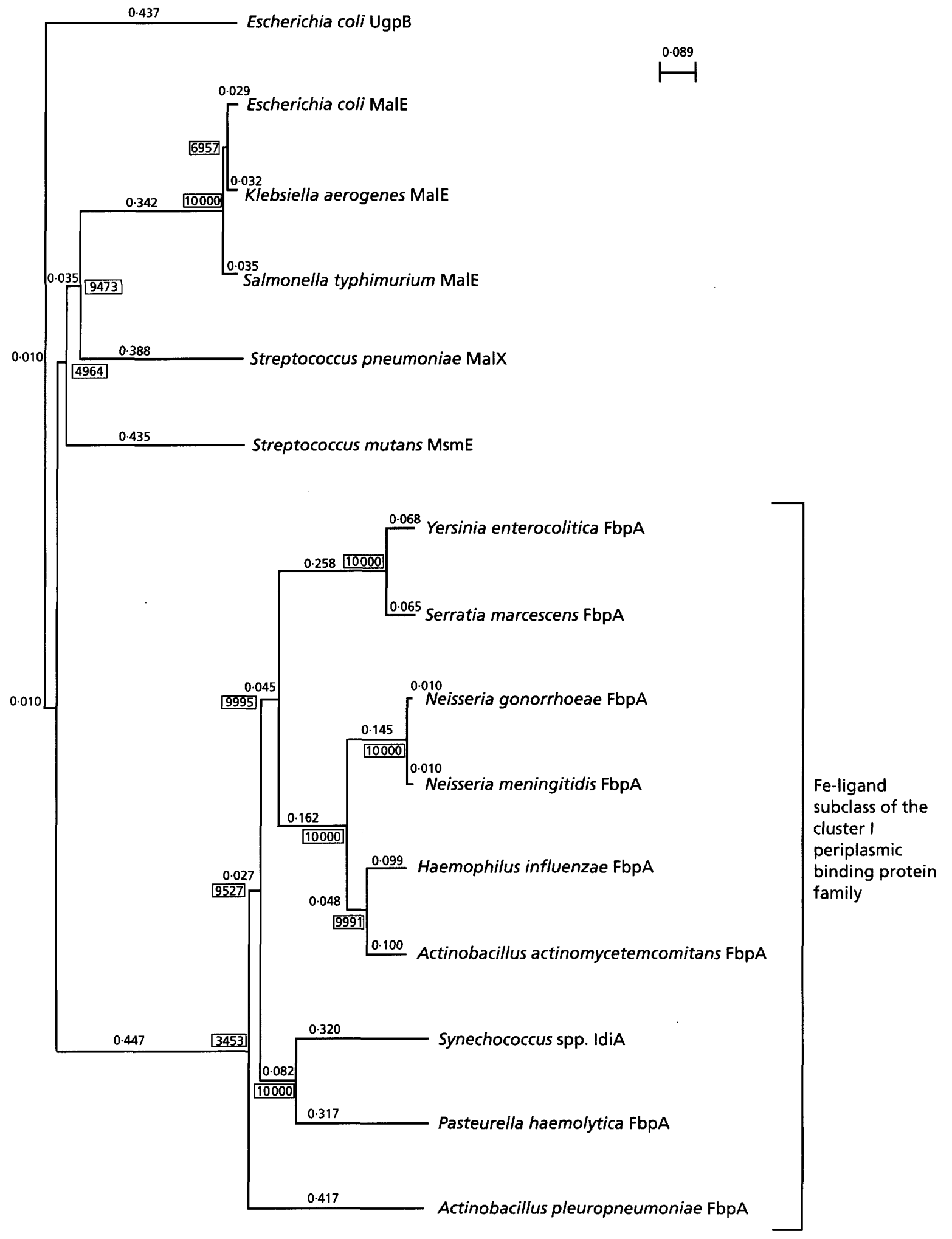

Fig. 4. Relationship of $P$. haemolytica FbpA to other members of the iron-binding protein subfamily and proteins of the cluster 1 group of extracellular solute-binding proteins (Tam \& Saier, 1993). Analysis was performed using the Power Macintosh versions of CLUSTAL W 1.6 (Higgins et al., 1996). Illustrated are relative genetic distances between proteins (fractional numbers) and bootstrap branching confidence values (out of 10000 samples, in boxes). 


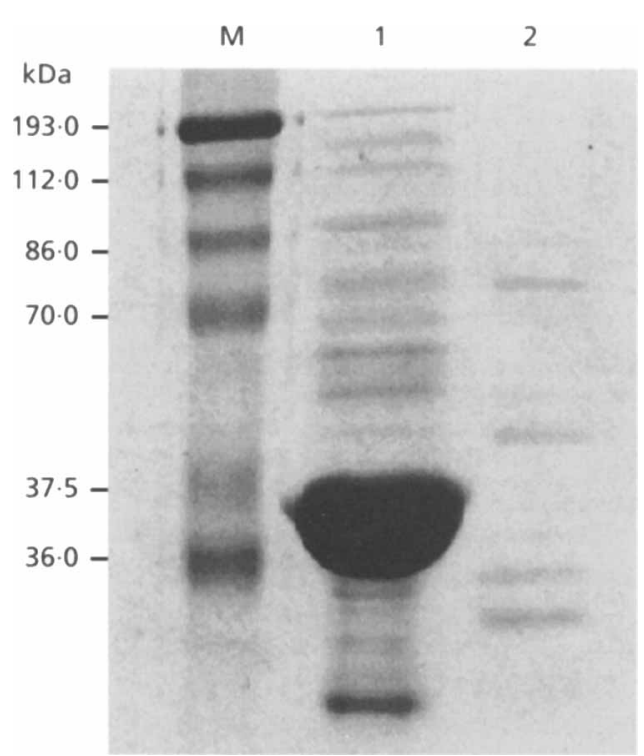

Fig. 5. Coomassie-stained $12 \%$ SDS-PAGE gel of holo-PFbpA protein produced by IPTG induction and concentrated osmotic shock fractionation from strain e1126 (pT7-7 PHFA) (lane 1), and an equivalent amount of sample produced by IPTG induction and concentrated osmotic shock fractionation from the negative control strain e1267 (pT7-7) (lane 2). Lane M contains prestained SDS-7B molecular mass markers (Sigma).

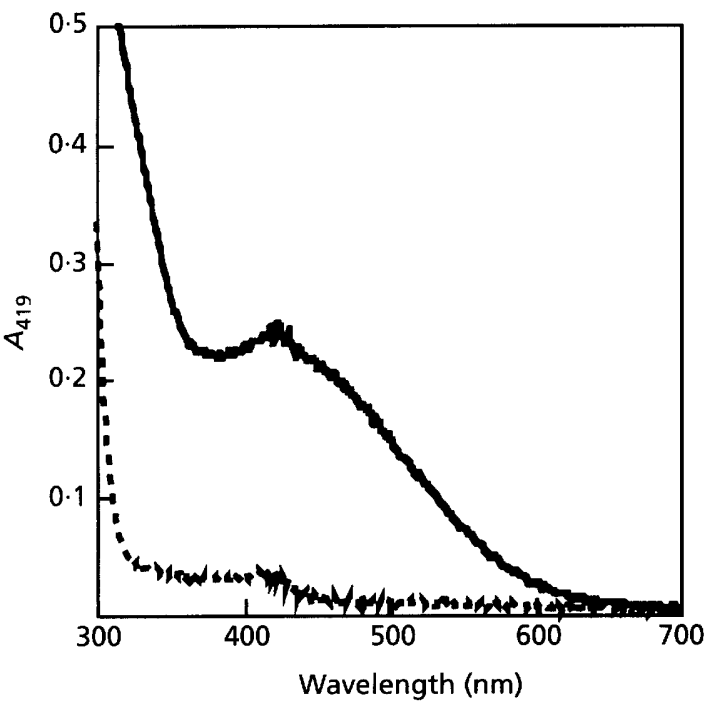

Fig. 6. Wavelength spectral scan from 300 to $700 \mathrm{~nm}$ of holo- (-) and apo- (- - ) forms of PFbpA.

chemical analyses (Fig. 5). Iron-loaded (holo-) and apoforms of PFbpA were subjected to wavelength scans from 300 to $700 \mathrm{~nm}$. Peak visible absorbance was determined to be $419 \mathrm{~nm}$ with an estimated molar absorption coefficient of $5426 \mathrm{M}^{-1} \mathrm{~cm}^{-1}$ (Fig. 6). Concentrated holo-PFbpA exhibits an orange-yellow coloration which is distinct from that of the reddish-pink coloration previously reported for holo- $H$. influenzae FbpA, Neisseria gonorrboeae FbpA and human transferrin (data not shown). Citrate competition assays confirmed a relative iron affinity similar to that reported for other FbpAs (approximate $K_{\mathrm{D}}$ of $10^{19}-10^{20}$; data not shown). IEF of PFbpA revealed an isoelectric point slightly less than that of $H$. influenzae FbpA at $\mathrm{pI} \sim 7.5$ (position -4 on a GADPH carbamylation train; Pharmacia) (data not shown).

\section{DISCUSSION}

We initially attempted to isolate the gene encoding the $35 \mathrm{kDa}$ protein using a PCR-based approach, designing oligonucleotides to amino acid sequences generated from the intact and a $\mathrm{CNBr}$-cleaved fragment of the $35 \mathrm{kDa}$ protein. However, we were unsuccessful at amplifying a specific PCR product from $P$. haemolytica chromosomal DNA during these experiments (data not shown). This may be in part attributable to the differences between the $\mathrm{N}$-terminal amino acid and DNA sequences of the $14 \mathrm{kDa}$ peptide (Table 2). We decided to pursue an alternative approach based on the method previously utilized by Zimmermann et al. (1989) to isolate the $s f u A B C$ operon from $S$. marcescens. We proceeded on the premise (i) that the $35 \mathrm{kDa}$ protein may be an $\mathrm{FbpA}$ homologue organized in a three-gene operon similar to that of other $f b p A B C$ operons, and (ii) these iron uptake systems may all share a similar affinity for iron, making it possible to clone the gene for the $35 \mathrm{kDa}$ protein based on the ability of the associated operon to complement an iron uptake mutant of $E$. coli. Using a $P$. haemolytica A1 lambda ZAP II library we were successful in identifying a clone capable of complementing an $e n t A$ E. coli strain on iron-restricted media. This clone was verified to be negative for siderophore production on the siderophore detection media of Schwyn \& Neilands (1987). DNA sequencing using M13F universal primer and Western blotting using an anti-35 $\mathrm{kDa} \mathrm{mAb}$ verified that the plasmid $\mathrm{pBSPH} 1$ possessed a translatable sequence which corresponded with the N-terminal amino acid sequence of the $35 \mathrm{kDa}$ protein, and that the strain e638 produced a $35 \mathrm{kDa}$ protein cross-reactive with the $\mathrm{mAb}$. Overexpression and purification of this protein revealed reversible iron binding with a peak absorbance at $419 \mathrm{~nm}$ and a relative iron affinity similar to that reported for FbpAs from $H$. influenzae and N. gonorrboeae.

Complete sequence analysis of pBSPH1 identified three genes in tandem arrangement with motifs characteristic of bacterial ABC importer systems (Higgins, 1992) and in particular, the three-component iron uptake operons within this family of transporters. Members of this 'operon' transporter family have been identified in a number of eubacterial species, including: $N$. gonorrhoeae (Berish et al., 1990b), Neisseria meningitidis (Berish et al., 1990a), $H$. influenzae (Sanders et al., 1994), Actinobacillus actinomycetemcomitans (GenBank accession number 2340838), $S$. marcescens (Angerer et al., 1990), Yersinia enterocolitica 
(GenBank accession number Z47200) and Actinobacillus pleuropneumoniae (Chin et al., 1996). All of these species are obligate or opportunistic human or veterinary pathogens. It is interesting to note that the sequence similarities between the FbpA components of different species are strongly associated with host and environment, but not necessarily associated with taxonomic groups. Thus, there is little overall sequence similarity between FbpA proteins among members of the Pasteurellaceae [A. pleuropneumoniae (source of porcine pleuropneumonia), $P$. haemolytica (bovine shipping fever), A. actinomycetemcomitans (human periodontal disease) and H. influenzae (Haemophilus meningitis, otitis media)], while human mucosal pathogens $[(A$. actinomycetemcomitans, $H$. influenzae, $N$. gonorrhoeae (gonorrhoea) and $N$. meningitidis (meningococcal meningitis)] and human enteric species $[S$. marcescens (urinary tract infection, septicaemia) and Y. enterocolitica (gastroenteritis)] form distinct clusters (Fig. 4).

Most surprising to us was the fact that PFbpA is more closely related to the $34 \mathrm{kDa}$ protein IdiA ( $\sim 40 \%$ identity) from the free-living cyanobacteria Synechococcus and Synechocystis spp. than to any of the aforementioned $\mathrm{FbpA}$ homologues from human or veterinary pathogens $(\sim 20-26 \%$ identity; Fig. 3; Klaus-Peter et al., 1996; Kaneko et al., 1995). IdiA has been demonstrated to be involved in the mobilization of both $\mathrm{Fe}$ and $\mathrm{Mn}$ necessary for growth and photosynthetic activity under $\mathrm{Fe}$ and/or $\mathrm{Mn}$ limitation in these species. To further compound our surprise, however, was the fact that IdiA is a not a periplasmic protein, but rather is associated with thylakoid membranes (photosynthetic pseudoorganelles) within the cytoplasm of the cell. Both in this investigation (on the basis of an osmotic shock purification scheme and biochemical characterization) and in a previous study (Lainson et al., 1991) it has been demonstrated that PFbpA is a periplasmic protein that reversibly and with high affinity associates with iron. As this protein and its cognate inner-membrane receptor complex were cloned functionally on the basis of their ability to rescue a siderophore-deficient strain of $E$. coli for growth under iron-limited conditions, it can be concluded that the PFbpABC operon is an iron $\mathrm{ABC}$ uptake transporter system, despite the similarity of PFbpA to IdiA. It is an interesting example of biological conservation, however, that two highly related iron-binding proteins have been adapted to different roles and subcellular locations within different species of eubacteria.

The recent resolution of the crystal structure of the $H$. influenzae FbpA (HFbpA) protein (Bruns et al., 1997) has provided some insight into the origins and function of this class of proteins. Structural data reveal that $\mathrm{HFbpA}$ is, in addition to being an iron-binding protein, a phosphate-binding protein. Complexed exogenous phosphate provides a necessary free $\mathrm{O}$ ligand for iron binding and is a structural analogue of the carbonate anion necessary for iron binding by transferrins and lactoferrins. Both transferrin N-lobe and HFbp bind iron with a similar spectrum of ligands $\langle\mathrm{H} 249$, Y95, $\mathrm{Y} 188$, D63 and two $\mathrm{O}$ ligands from exogenous $\mathrm{CO}_{3}$ in transferrin; H9, Y195, Y196, E57, one O ligand from exogenous $\mathrm{PO}_{4}$ and one $\mathrm{O}$ ligand from $\mathrm{H}_{2} \mathrm{O}$ in $\mathrm{HFbp}$ ), however the source of these ligands is non-analogous regions of the primary structure of these proteins. There is also extremely low sequence identity between the $\mathrm{N}$-lobe of transferrin and HFbp $(\sim 10 \%)$. This, coupled with the fact that HFbp has more in common structurally with sugar- and anion-binding periplasmic proteins than transferrin, has led to the proposal that high-efficiency iron-binding has evolved independently multiple times over the course of evolution and, in the case of HFbp, has resulted from selective pressure for a phosphate-binding protein to associate avidly, but reversibly, with iron. A central $\alpha$-helix implicated in anion binding appears to be the most structurally universal motif conserved between HFbp, sulfate- and phosphate-binding proteins.

Despite low sequence identity, two of the four amino acids involved in iron binding (Y198 and Y199) based on primary sequence alignment can be identified by alignment of PFbpA with HFbpA (Fig. 3). In addition, three of the six amino acids implicated in $\mathrm{PO}_{4}$ binding in HFbp (Q58, N175, N193 and the $\alpha$-helix S139, G140, A141) are also present in PFbp, including N196 and what appears to be a homologue of the central anion $\alpha$ helix: S137, G138, K139. Currently ongoing crystallographic analysis of this protein should reveal whether it also binds phosphate or instead uses an alternative exogenous anionic ligand. Differences in the anion- or iron-binding ligands in PFbpA may be responsible for the blue-shifted absorbance spectra of this protein. Preliminary crystallographic diffraction data reveal that PFbpA cannot be exactly modelled on the HFbpA crystal structure, indicating that structural differences do exist between these two proteins (D. McRee, personal communication).

Early in our work we had anticipated a large degree of sequence conservation in the $\mathrm{FbpA}$ homologues between the various pathogenic members of the Pasteurellaceae, including the representative species $P$. haemolytica (bovine pathogen), A. pleuropneumoniae (porcine pathogen) and $H$. influenzae (human pathogen). This postulate was based on the proposal that FbpA represents a critical component of transferrin-receptormediated iron uptake pathways and, due to constraints of protein-protein interactions with other components of the uptake pathway (i.e. FbpB and possibly TbpA), would be restricted in the degree of permissible variation which would continue to allow this system to remain functional. Furthermore, as FbpA is a periplasmic entity it would not be expected to be under immunological pressure for variation and therefore should not vary more than any cellular 'house keeping' genes. It must be stated that it has been suggested that FbpA may be transiently surface-exposed (Gomez et al., 1996). However, the majority of the evidence, including that for PFbpA, suggests that this protein is predominantly a periplasmic entity (Lainson et al., 1991; Berish et al., 
1992). It has now become apparent from the numerous $f b p A$ gene sequences available that, although highly conserved between different biovariants within species (Murray et al., 1992; Genco et al., 1994), there exists an enormous degree of sequence divergence in this gene between species (Fig. 4). This is surprising given the fact that other proteins, such as a $31 \mathrm{kDa}$ iron-regulated periplasmic protein found in both $H$. influenzae and $P$. haemolytica, appear to be strongly conserved with $\sim 95 \%$ identity over available sequence (Harkness $\mathrm{et} \mathrm{al}$., 1992; Tabatabai \& Frank, 1997). This would suggest that it is not lack of phylogenetic overlap which is responsible for the degree of sequence divergence in $f b p A$ between species, but perhaps biological constraints dictating variation. If $\mathrm{FbpA}$ directly interacts with surface receptors during iron uptake, one possible explanation for this divergence could be that immunological pressure for antigenic variation in TbpA and $\mathrm{TbpB}$ may have resulted in co-variation in $\mathrm{FbpA}$, such that protein-protein interactions between the surface receptors and their cognate periplasmic protein remain viable for iron uptake. Although it remains to be demonstrated whether FbpA directly interacts with transferrin or lactoferrin surface receptor proteins in any species which possess this iron uptake strategy, that FbpA is necessary for transferrin iron uptake has been verified by the fact that mutant strains incapable of producing $\mathrm{FbpA}$ are abrogated in high-efficiency iron acquisition from transferrin and free iron salts in $H$. influenzae (Kirby et al., 1997) and transferrin, lactoferrin and free iron salts in N. meningitidis (Khun et al., 1998). It is likely that PFbpA functions in a similar capacity with the $P$. haemolytica Tbp A/B proteins, for which the corresponding genes have recently been cloned and sequenced (Ogunnariwo et al., 1997).

Within the cluster 1 group of periplasmic binding proteins, PFbpA and, to a greater extent, A. pleuropneumoniae FbpA, stand out as highly divergent from other members of this iron-binding protein subfamily (Fig. 4). It could be suggested that this divergence may have been the result of isolation of these pathogens from other members of the Pasteurellaceae as a result of the development of host specificity (at least in part due to specificity of bacterial transferrin receptors for their cognate host transferrin) (Schryvers \& Gonzalez, 1990). However, the strong degree of identity between not only the $P$. baemolytica $f b p A$ gene and that of homologues identified within Synechococcus and Synechocystis spp., but also between $P$. haemolytica $\mathrm{FbpB}$ ( $\sim 42 \%$ identity vs $\sim 17-24 \%$ of other FbpBs) and P. haemolytica FbpC $(44 \%$ identity vs $\sim 32-38 \%$ ) and homologues within these cyanobacteria is a curiosity, as obviously the cyanobacteria have diverged from the Pasteurellaceae long before the development of host specificity within the Pasteurellaceae. We cannot, however, give a rational explanation for how such a relationship could have developed, although the limitations of phylogenetic analysis and the complications of horizontal genetic transfer have been well-documented by others (Syvanen, 1994).
Although resistance to challenge infection by $P$. haemolytica serotype $\mathrm{A} 1$ in sheep has been demonstrated to be correlated with a rise in titre of anti-35 kDa serum antibodies (possibly anti-PFbpA) (Mosier et al., 1989) and the $35 \mathrm{kDa}$ protein is highly immunogenic in sheep (Lainson et al., 1991), it is unlikely that the $35 \mathrm{kDa}$ protein ( $\mathrm{PFbpA}$ ) alone could make an effective immunoprophylactic target given its lack of surface accessibility. However, it is unknown whether the strong humoral response to PFbpA could augment overall immune response to $P$. haemolytica infection. It has recently been suggested that FbpA could make a potential chemotherapeutic target, given the recent understanding of the mechanism of iron binding revealed by the crystal structure of HFbpA (Bruns et al., 1997). This is supported by the facts that iron acquisition is a critical component of bacterial pathogenesis in vivo and $\mathrm{FbpA}$ is a focal point for high-affinity iron uptake from both free iron sources and iron complexed by transferrin and lactoferrin within the host. Despite low overall sequence identity, it appeared that the mechanism of iron binding by FbpA was universally conserved between different species, as the core iron-binding ligands could be identified in all representative members of this protein; an attractive feature for a broad-spectrum target. However, the recent identification of 'outliers' for which these iron-binding ligands cannot be identified in primary sequence alignments of PFbpA and, to a larger extent, A. pleuropneumoniae $\mathrm{FbpA}$ underscores the question of whether alternative mechanisms of iron binding exist in these related pathogens. Structural information on these proteins will answer this question and may reveal whether FbpA should be further pursued as a target for antibacterial therapy.

\section{ACKNOWLEDGEMENTS}

This investigation was supported by grant no. MT-10350 from the Medical Research Council of Canada (ABS). S.D.K was supported by a studentship from the Alberta Heritage Foundation for Medical Research and a scholarship from the Japanese Ministry of Culture, Education and Science (Monbusho).

\section{REFERENCES}

Adhikari, P., Kirby, S. D., Nowalk, A. J., Veraldi, K. L., Schryvers, A. B. \& Mietzner, T. A. (1995). Biochemical characterization of a Haemophilus influenzae periplasmic iron transport operon. J Biol Chem 42, 25142-25149.

Adhikari, P., Berish, S. A., Nowalk, A. J., Veraldi, K. L., Morse, S. A. \& Mietzner, T. A. (1996). The $f b p A B C$ locus of Neisseria gonorrboeae functions in the periplasm-to-cytosol transport of iron. J Bacteriol 178, 2145-2149.

Angerer, A., Gaisser, S. \& Braun, V. (1990). Nucleotide sequences of the $s f u A, s f u B$ and $s f u C$ genes of Serratia marcescens suggest a periplasmic-binding-protein-dependant iron transport mechanism. J Bacteriol 172, 572-578.

Berish, S. A., Kapczynski, D. R. \& Morse, S. A. (1990a). Nucleotide sequence of the Fbp gene from Neisseria meningitidis. Nucleic Acids Res 18, 4596.

Berish, S. A., Mietzner, T. A., Mayer, L. W., Genco, C. A., 
Holloway, B. P. \& Morse, S. A. (1990b). Molecular cloning and characterization of the structural gene for the major iron regulated protein expressed by Neisseria gonorrhoeae. J Exp Med 171, 1535-1546.

Berish, S. A., Chen, C.-Y., Mietzner, T. A. \& Morse, S. A. (1992). Expression of a functional neisserial $f b p$ gene in Escherichia coli. Mol Microbiol 6, 2607-2615.

Burland, V., Plunkett, G., III, Sofia, H. J., Daniels, D. L. \& Blattner, F. R. (1995). Analysis of the Escherichia coli genome. VI. DNA sequence of the region from 92.8 through 100 minutes. Nucleic Acids Res 23, 2105-2119.

Bruns, C. M., Nowalk, A. J., Arvai, A. S., McTigue, M. A., Vaughan, K. G., Mietzner, T. A. \& McRee, D. E. (1997). Structure of Haemophilus influenzae $\mathrm{Fe}(+3)$-binding protein reveals convergent evolution within a superfamily. Nat Struct Biol 4, 919-924.

Chen, C.-Y., Berish, S. A., Morse, S. A. \& Mietzner, T. A. (1993). The ferric iron-binding protein of pathogenic Neisseria spp. functions as a periplasmic transport protein in iron acquisition from human transferrin. Mol Microbiol 10, 311-318.

Chin, N., Frey, J., Chang, C. \& Chang, Y. (1996). Identification of a locus involved in the utilization of iron by Actinobacillus pleuropneumoniae. FEMS Microbiol Lett 143, 1-6.

Deneer, H. G. \& Potter, A. A. (1989). Iron-repressible outermembrane proteins of Pasteurella haemolytica. J Gen Microbiol 135, 435-443.

Eick-Helmerich, K., Hantke, K. \& Braun, V. (1987). Cloning and expression of the exbB gene of Escherichia coli K-12. Mol Gen Genet 206, 246-251.

Genco, C. A., Berish, S. A., Chen, C.-Y., Morse, S. \& Trees, D. L. (1994). Genetic diversity of the iron-binding protein ( $\mathrm{Fbp}$ ) gene of the pathogenic and commensal Neisseria. FEMS Microbiol Lett 116, 123-130.

Gomez, J. A., Agra, C., Ferron, L., Powell, N., Pintor, M., Criado, M. T. \& Ferreiros, C. M. (1996). Antigenicity, cross-reactivity and surface exposure of the Neisseria meningitidis $37 \mathrm{kDa}$ protein (Fbp). Vaccine 14, 1340-1346.

Gray-Owen, S. D. \& Schryvers, A. B. (1996). Bacterial transferrin and lactoferrin receptors. Trends Microbiol 4, 185-191.

Harkness, R. E., Chong, P. \& Klein, M. H. (1992). Identification of two iron-repressed periplasmic proteins in Haemophilus influenzae. J Bacteriol 174, 2425-2430.

Higgins, C. F. (1992). ABC transporters: from microorganisms to man. Annu Rev Cell Biol 8, 67-113.

Higgins, D. G., Thompson, J. D. \& Gibson, T. J. (1996). Using CLUSTAL for multiple sequence alignments. Methods Enzymol 266, 383-402.

Innis, M. A. \& Gelfand, D. H. (1990). PCR Protocols: a Guide to Methods and Applications, pp. 3-12. Edited by M. A. Innis, D. H. Gelfand, J. J. Sninsky \& T. J. White. San Diego: Academic Press.

Kaneko, T., Tanaka, A., Sato, S., Kotani, H., Sazuka, T., Miyajima, N., Sugiura, M. \& Tabata, S. (1995). Sequence analysis of the genome of the unicellular cyanobacterium Synechocystis sp. strain PCC 6803. I. Sequence features in the $1 \mathrm{Mb}$ region from map positions $64 \%$ to $92 \%$ of the genome. DNA Res $2,153-166$.

Khun, H., Kirby, S. D. \& Lee, B. C. (1998). A Neisseria meningitidis $f b p A B C$ mutant is incapable of using nonheme iron for growth. Infect Immun 66, 2330-2336.

Kirby, S. D., Gray-Owen, S. D. \& Schryvers, A. B. (1997). Characterization of a ferric-binding protein mutant in Haemophilus influenzae. Mol Microbiol 25, 979-987.
Klaus-Peter, M., Thole, H. H. \& Pistorius, E. K. (1996). IdiA, a $34 \mathrm{kDa}$ protein in the cyanobacteria Synechococcus sp. strains PCC 6301 and PCC 7942, is required for growth under iron and manganese limitations. Microbiology 142, 2635-2645.

Laemmli, U. K. (1970). Cleavage of structural proteins during the assembly of the head of bacteriophage T4. Nature 227, 680-685.

Lainson, F. A., Harkins, D. C., Wilson, C. F., Sutherland, A. D., Murray, J. E., Donachie, W. \& Baird, G. D. (1991). Identification and localization of an iron-regulated $35 \mathrm{kDa}$ protein of Pasteurella haemolytica serotype A2. J Gen Microbiol 137, 219-226.

Liss, L. R. (1987). New M13 host: $\mathrm{DH} 5 \alpha \mathrm{F}^{\prime}$ competent cells. $B R L$ Focus 9, 13.

Mietzner, T. A. \& Morse, S. A. (1994). The role of iron-binding proteins in the survival of pathogenic bacteria. Annu Rev Nutr 14, 471-493.

Mosier, D. A., Simons, K. R., Confer, A. W., Panciera, R. J. \& Clinkenbeard, K. D. (1989). Pasteurella haemolytica antigens associated with resistance to pneumonic pasteurellosis. Infect Immun 57, 711-716.

Murray, J. E., Davies, R. C., Lainson, F. A., Wilson, C. F. \& Donachie, W. (1992). Antigenic analysis of iron-regulated proteins in Pasteurella baemolytica A and T biotypes by immunoblotting reveals biotype-specific epitopes. J Gen Microbiol 138, 283-288.

Ogunnariwo, J. A. \& Schryvers, A. B. (1990). Iron acquisition in Pasteurella haemolytica: expression and identification of a bovine-specific transferrin receptor. Infect Immun 58, 2091-2097.

Ogunnariwo, J. A., Woo, T. K. W., Lo, R. Y. C., Gonzalez, G. C. \& Schryvers, A. B. (1997). Characterization of the Pasteurella haemolytica transferrin receptor genes and the recombinant receptor proteins. Microb Pathog 23, 273-284.

Riggs, P. (1994). Expression and purification of maltose binding protein fusions, pp. 16-6-1 to 16-6-14. In Current Protocols in Molecular Biology, vol. 2. Edited by F. M. Ausubel, R. Brent, R. E. Kingston, D. D. Moore, J. G. Seidman, J. A. Smith \& K. Struhl. New York: Wiley.

Sambrook, J., Fritsch, E. F. \& Maniatis, T. (1989). Molecular Cloning: a Laboratory Manual, 2nd edn. Cold Spring Harbor, NY: Cold Spring Harbor Laboratory.

Sanders, J. D., Cope, L. D. \& Hansen, E. J. (1994). Identification of a locus involved in the utilization of iron by Haemophilus influenzae. Infect Immun 62, 4515-4525.

Saurin, W., Köster, W. \& Dassa, E. (1994). Bacterial binding protein-dependent permeases: characterization of distinctive signatures for functionally related integral cytoplasmic membrane proteins. Mol Microbiol 12, 993-1004.

Schryvers, A. B. \& Gonzalez, G. C. (1990). Receptors for transferrin in pathogenic bacteria are specific for the host's protein. Can J Microbiol 36, 145-147.

Schwyn, B. \& Neilands, J. B. (1987). Universal chemical assay for the detection and determination of siderophores. Anal Biochem 160, 47-56.

Shine, J. \& Dalgarno, L. (1974). The 3'-terminal sequence of Escherichia coli $16 \mathrm{~S}$ ribosomal RNA: complementarity to nonsense triplets and ribosome binding sites. Proc Nat Acad Sci USA 71, 1342-1346.

Syvanen, M. (1994). Horizontal gene transfer: evidence and possible consequences. Annu Rev Genet 28, 237-261.

Tabatabai, L. B. \& Frank, G. H. (1997). Purification and characterization of a 31-kilodalton iron regulated periplasmic protein from Pasteurella haemolytica A1. Prep Biochem Biotechnol 170, 253-269. 
Tabor, S. (1994). Expression using the T7 RNA polymerase/ promoter system, pp. 16-2-1 to 16-2-11. In Current Protocols in Molecular Biology, vol. 2. Edited by F. M. Ausubel, R. Brent, R. E. Kingston, D. D. Moore, J. G. Seidman, J. A. Smith \& K. Struhl. New York: Wiley.

Tam, R. \& Saier, M. H., Jr (1993). Structural, functional, and evolutionary relationships among extracellular solute-binding receptors of bacteria. Microbiol Rev 57, 320-346.

Williamson, C. A. \& Slocum, R. D. (1994). Isolation of cDNA clones by complementation of $E$. coli mutants with infective pBluescript phagemid libraries. Biotechniques 16, 986-988.

Zimmermann, L., Angerer, A. \& Braun, V. (1989). Mechanistically novel iron (III) transport system in Serratia marcescens. J Bacteriol 171, 238-243.

Received 25 June 1998; revised 26 August 1998; accepted 9 September 1998. 